Review

\title{
DNA Markers for Food Products Authentication
}

\section{Daria Scarano and Rosa Rao *}

Department of Agriculture, University of Naples "Federico II", Via Università 100, Portici 80055, Italy; E-Mail: daria.scarano@unina.it

* Author to whom correspondence should be addressed; E-Mail: rao@unina.it; Tel.: +39-081-25-39204.

Received: 1 August 2014; in revised form: 1 September 2014 / Accepted: 2 September 2014 /

Published: 5 September 2014

\begin{abstract}
Media constantly refer of unscrupulous producers that adulterate, alter or replace premium products in food chains with the goal to maximize illegally profits. Food traceability is a central issue for the identification of improper labeling of processed food and feed and there are rules aimed to protect consumers and producers against fraudulent substitution of quality products in food chain, but the tools available are not always appropriate. DNA-based markers proved very effective for fresh and processed food molecular authentication. In this review, we illustrate potential and limits of different DNA markers focusing on low, medium and high-throughput markers, in order to monitor the genetic identity of food components in meat, fish and plants net-chains.
\end{abstract}

Keywords: food traceability; SSR; SNP; DNA barcoding

\section{Introduction}

The increased awareness of the value of food quality is reflected in an increased request by consumers of assurances regarding the origin and content of the food they buy. At the same time, companies must be able to confirm the authenticity of their products, to comply with the regulations and to protect their products from global competition. For these reasons, the identification of the origin of the ingredients present in food or feed and the characterization of materials entering and exiting the food chains are of particular relevance. At present, the protection of the rights of consumers and producers and the prevention of fraudulent actions are issues of growing importance and mandatory for the food industry. These issues can now be addressed more efficiently than in the past, thanks to the activation of a traceability system which should allow the stakeholder of the food net to identify the 
immediate supplier and the immediate subsequent recipient of the product, according to the principle that at every stage of the supply net information should be readily available about one step back and one step forward with the exception of retail sale. Such a system of traceability is crucial in an advanced economy, not only because it allows consumers to have accurate information and control on the food, but also because it facilitates the withdrawal of foods in case of problems.

All food products must comply with the description provided by the manufacturers or processors, with reference to the origin of the ingredients, details of the transformation process, the geographic origin and the identity of the species, breeds or varieties used. The partial or complete replacement with cheaper components is one of the most common frauds to the consumers and producers.

The tools for the authentication of foods are different, and include protein, metabolite and DNA analyses. The protein-based methods rely on immunological [1] or electrophoretic and chromatographic assays [2] while the metabolite analysis is based mainly on HPLC [3,4], NMR [5,6] and MS [7,8]. Unfortunately, the protein and metabolite assays often suffer from inconsistencies due to farming system and processing methods, as they are affected by environmental conditions and industrial procedures $[9,10]$. On the contrary, DNA-based methods are more reliable, thanks to the stability of DNA under production and processing techniques applied along the food-chain.

Therefore, DNA markers offer a powerful tool to address the validation of food authenticity and traceability of primary products entering the food chains both in fresh and processed food.

In this review, we give an overview of the use of different DNA markers in food authentication and traceability.

\section{DNA Markers}

DNA markers identify variations of the nucleotide sequence of a genome that can highlight inter and intra-species diversity. They have high information potential due to their large number and their stability. The analysis of polymorphic DNA markers is used in multiple applications that include the evaluation and characterization of genetic variation, the construction of molecular maps and marker-assisted selection.

According to the throughput, the most common DNA markers can be classified into three major groups: low-, medium- and high-throughput. The former are hybridization-based markers such as Restriction Fragment Length Polymorphisms (RLFP), the medium-throughput are PCR-based markers that include Random Amplified Polymorphic DNA (RAPD), Amplified Fragment Length Polymorphism (AFLP), Simple Sequence Repeat (SSR), also known as microsatellite, and DNA barcoding, while the latter are sequence-based markers like Single Nucleotide Polymorphism (SNP).

RFLP were the first markers used to analyze inter and intra-species genetic variability at genomic level. DNA variations can be highlighted by comparing the digested DNA patterns of different samples (i.e., species or varieties). RFLP markers have been widely employed for several purposes, as they are reproducible and co-dominant, such as the construction of linkage maps in several species including Solanum lycopersicum and Zea mays [11,12] and the authentication of seafood products [13]. However, the detection of RFLPs is an expensive, labor- and time-consuming process, not amenable to automation, and it is, presently, considered obsolete. 
PCR-based methods involve the amplification of DNA fragments using specific or arbitrary primers. Amplicons can be separated by electrophoresis and visualized by different technologies. RAPDs are able to detect, concurrently, loci in several regions of a genome. Although most of the RAPD markers are dominant, and therefore do not allow to distinguish whether the amplified DNA segment is heterozygous or homozygous at a particular locus, RAPD analysis has been widely used for taxonomic and phylogenetic studies [14,15] for species differentiation [16,17] and to study phylogeographic patterns of genetic variations $[18,19]$. However, RAPD technique requires maintaining strictly consistent reaction conditions in order to achieve reproducible profiles [20].

DNA polymorphisms can also be revealed by AFLPs; unlike RAPDs, this technique is highly reproducible as it combines restriction digestion and PCR. Although technically demanding, AFLP markers are still in vogue in molecular genetics research also because they are able to reveal variability in closely related genotypes [21-24].

SSR markers are composed by tandem repeated motifs of 2-6 bp, representing the core of the microsatellite, that can be amplified using the unique flanking region for primers annealing. SSRs are highly reproducible, highly polymorphic, and amenable to automation [25]. For these reasons SSRs have been considered for many years as "markers of choice" [26]. They were successfully employed in varietal identification and proved to be very effective for the authentication of food components, both of animal and plant origin [27-33]. In addition, SSRs represent a very useful tool for paternity analysis, construction of high-density genome maps, marker-assisted selection, and for establishing genetic and evolutionary relationships [34].

Recently, SNP markers, caused by the replacement of a single nucleotide, have become the most used markers in genetic characterization studies as well as in translational genomic [35]. SNPs are, in fact, the most abundant forms of genetic variation among individuals of a species.

In tomato, it has been recently shown that population structure analysis based on SNP markers allowed the characterization and discrimination of landraces and varieties [36-38]. In addition, in cacao seeds, SNP fingerprints allowed the identification of an adulterant variety [39].

Beside nuclear genome, organellar genomes, have been proposed as a valuable tool for species discrimination [40-44]. DNA markers developed from mitochondrial genome were proposed as DNA barcode that is a standard region of the genome, which is usually characterized by a high inter-specific, and low intra-specific variability [45]. The DNA sequence successfully used in DNA barcoding in animals is the $5^{\prime}$ end of the mitochondrial gene cytochrome oxidase 1 (coxl or CO1). This sequence is recognized as universal barcode of the kingdom Animalia and is used to authenticate and trace animal species and breeds [46-49]. On the contrary in plants mitochondrial genome did not show similar power in species discriminations, possibly because of intra-molecule recombination that characterizes plant mitochondrial DNA [50]. For this reason, the attention focused on plastid genes. Several combinations of seven plastid genes ( $r p o C 1+r p o B+m a t K$ or $r p o C 1+m a t K+t r n H-p s b A, r b c L+t r n H-p s b A$ and $a t p F-H+p s b K-I+m a t K)$ were initially proposed as candidate barcoding markers [40,51]. Subsequently, Lahaye and co-workers [52] proposed mat $K$ as major plant barcode. To facilitate the selection of the proper plant barcode, the Consortium for the Barcode of Life (CBOL) promoted the formation of a working group in order to test the candidate barcoding markers. The best option for plant barcode resulted to be a core-barcode, consisting of portions of two plastid-coding regions, $r b c L+m a t K$, to be supplemented with additional markers as required. The combination of these two 
regions was chosen because of the high level of recoverability of high-quality sequences and high levels of species discrimination [53]. In order to facilitate barcode data analyses, the Barcode of Life Data System (BOLD) [54] provides an integrated bioinformatics platform for data collection and support of the barcode validation. As proposed by Ratnasingham and Hebert [55], BOLD is a repository for the specimen and sequence records that helps the management, quality assurance and analysis of barcode data, providing also a vehicle for collaboration among researchers.

DNA barcoding is used to provide insights into species-level taxonomy, to define and delimit species, and to assist in the process of assigning organisms to proper species. For example, an identification rate of $100 \%$ was realized in a study of 260 species of North American birds [56]. In addition, in a study on Diptera, an identification rate of $70 \%$ was achieved in identifying 449 species of flies, owing to an extensive overlap between intra- and interspecific variability [57]. COI barcoding helped also to validate a number of new fish species, including goby [58], sting ray, Antarctic ray Bathyraja [59], handfish Brachionichthys australis [60], and five new species of damselfish of the genus Chromis [61].

\section{Food Frauds and Genetic Traceability}

Information on a food product is essential for consumers to let them choosing one food product over another. The choice can reflect lifestyle, religious concerns (e.g., vegetarianism, preference for organic products, absence of pork for Jews and Muslims), or health concerns (e.g., absence of peanuts, lactose or gluten for individuals with particular allergies).

For these reasons erroneous description and mislabeling of a food product are illegal, particularly if the food has been processed removing the ability to distinguish the components.

There are several different ways in which a food product can be mislabel; examples are represented by the substitution of one component by a similar but cheaper one; the presence of undeclared ingredients; the false extension of the shelf life; non-declaration or false declaration of processes; the over-declaration of a quantitative ingredient; false claims regarding geographical or production origin.

The European Union (EU) food legislation protects consumers against fraudulent or deceptive business practices. In 2002 the traceability was defined as "the ability to trace and follow a food, feed, an animal or substance intended to become part of a food or feed, through all stages of production, processing and distribution" (EU regulation No. 178/2002).

Most common traditional tracking systems are alphanumerical label, bar-codes and radio frequency identification (RFID) system in which are included information about processes, companies, production areas, and everything that happens to the product before, during, and after the manufacturing and packaging. However, alphanumerical codes are not frequently used: the management requires human resources because code writing and code reading are not automatic. Furthermore, performance is not exceptionally good: problems are associated with the large amount of managed manually data and the risk of data integrity corruption is very high [62]. In a bar-code system, every time an item is moved from one point to another, its bar-code label must be upgraded. However, the system is easily damaged and is, therefore, not very attractive for the food sector. RFID is an identification tool that uses wireless microchips to generate tags that do not need physical contact or particular alignment with the reader. The reading phase is very fast and fully automated. Furthermore, RFID tags are very small and they have no compatibility problem with foods. However, tags may be very expensive (up to $20 €$ each) 
making the system difficult choice by stakeholders [62]. In addition, none of the previously mentioned methods guarantees the consumers from substitutions of row materials and undeclared ingredients.

Considering that any statement concerning the presence of a species, breed or cultivar in a food necessarily involves a genetic analysis, DNA-based techniques appear the ideal tracking tool also able to prevent frauds. The direct identification of DNA polymorphism allows to authenticate row and processed food components as DNA polymorphisms may detect and univocally identify a genotype. Moreover, species or cultivated varieties identification and authentication based on DNA analysis can be performed, at least in principle, on any tissue as DNA can be extracted from very different matrices [63].

For example, mitochondrial DNA markers $\mathrm{CO} 1$ demonstrated to be effective for the characterization of animal species in food products. This DNA barcode was employed for the discrimination of a high number of bovine breeds, for the analysis of fresh and degraded meat substrates and for the identification of mislabeled fishery products [46-49]. Similarly, in plants plastidial DNA, barcodes, such as $r b c L+m a t K$, may allow to discriminate plants for food uses as, for example, Ocimum species or poison plants of the Solanum genus [64,65].

Molecular traceability based on DNA molecular markers, such as SSRs, proved effective to protect premium products with European quality labels as, for example, the IPG label for beef certification "Ternera de Navarra" [28] or the PDO label for the tomato variety "San Marzano" [66]. Finally, DNA markers can also help in evaluating the amounts of different species that are present in a foodstuff or in checking the food label declaration. Examples are represented by the detection of soft wheat in durum wheat semolina or in some typical breads, with European quality label, made in Southern Italy (bread of Altamura and bread of Matera) that, according to the official protocol of production, must be prepared exclusively with durum wheat $[67,68]$.

Examples of DNA markers used in the analysis of food products are listed in Table 1.

Table 1. Examples of the use of DNA markers in the analysis of food products.

\begin{tabular}{|c|c|c|c|}
\hline & Food Product & Marker & References \\
\hline \multirow{19}{*}{ Plant } & Apple & SSR & [69] \\
\hline & \multirow[t]{7}{*}{ Olive oil } & AFLP & [70] \\
\hline & & AFLP & [71] \\
\hline & & RAPD, ISSR, SSR & [72] \\
\hline & & SNP, LDR & [73] \\
\hline & & SSR & {$[74]$} \\
\hline & & SSR & [68] \\
\hline & & SSR & {$[32]$} \\
\hline & Pasta & AFLP & {$[75]$} \\
\hline & Poisonus plants & DNA-barcoding & [64] \\
\hline & Rice & SSR & {$[76]$} \\
\hline & Spicies & DNA-barcoding & {$[65]$} \\
\hline & \multirow[t]{4}{*}{ Tomato } & SSR & [30] \\
\hline & & SSR & [66] \\
\hline & & SSR & [31] \\
\hline & & SSR & [29] \\
\hline & Wheat & SSR & [67] \\
\hline & \multirow[t]{2}{*}{ Wine } & cpSSR & {$[77]$} \\
\hline & & SSR, ISSR & [33] \\
\hline
\end{tabular}


Table 1. Cont.

\begin{tabular}{cccc}
\hline & Food Product & Marker & References \\
\hline \multirow{4}{*}{ Meat } & Cow & DNA-barcoding & {$[46]$} \\
& Beef & SSR & {$[28]$} \\
& Meat & SSR & {$[78]$} \\
& & RAPD & {$[79]$} \\
& Pig & DNA-barcoding & {$[47]$} \\
& Snchovy & DNA-barcoding & {$[81]$} \\
Cod & DNA-barcoding & {$[82]$} \\
& Fish & DNA-barcoding & {$[48]$} \\
& Mackerel & RFLP & {$[13]$} \\
Salmon & RAPD & {$[83]$} \\
& Shark & SNP & {$[84]$} \\
& Trout & DNA-barcoding & {$[49]$} \\
& Tuna & RAPD & {$[85]$} \\
& & RFLP & {$[86]$} \\
\hline
\end{tabular}

Here, we report some examples of DNA markers used towards the final goal to trace and authenticate fresh and processed food products.

\subsection{Meat}

The illegal substitution of high priced meats with low priced ones has become unfortunately common, being driven by strong financial incentives [87]. This behavior, in addition to misleading the consumer, threatens the producers of special breeds, weakening their brands and lowering market prices. In fact, in industrial abattoirs, individual meat cuts are difficult to be visually recognized once the carcass has been removed. Typically, meat cuts are tracked individually or in batches by tagging the container or using a carrier device. However, during transportation tags or devices may be accidentally or deliberately removed.

Over the last few years DNA based methods were proposed for meat identification $[27,28,88,89]$. Indeed, SSR markers proved effective in differentiating groups of cattle from the same breed [90] and pure wild boar meat, a premium product with higher market price, from pure pig breed [91]. In addition, SSRs were successfully used to identify species mixtures in processed products, such as sausages, salamis, and patés [92].

SSRs and SNPs were tested in a comparative study on bovine Angus herd in order to examine the amount of information provided by both markers. The minimum number of markers recommended by the ISAG (International Society for Animal Genetics) for bovine genetic identification is a set of 12 SSRs and the comparative analysis revealed that two SNPs were necessary to provide the same statistically significant discrimination power of one SSR. However, even though SSRs are multiallelic and highly polymorphic, SNPs seems to be less affected by consanguinity and population structure than SSRs [92]. Using different methodologies for SNPs detection, several papers demonstrate that is possible to use this type of maker for meat traceability with high levels of accuracy underlining the possibility to link an individual piece of meat with the animal breed [80,93]. By the use of the 
Sequenom's MaSSaRRaY@ system,80 SNPs for pig discrimination were successfully tested and are now available for pig breeds identification [94]. The availability of SNP chips for many livestock species actually offers a novel and powerful tool for genetic identification assays designed for regulatory purposes. An example is represented by the PorcineSNP60 bead-chip and its derivative that allow to identify mislabeling, providing a tool for food forensics [95,96].

On the other hand, Hebert and collaborators [45] proposed the DNA barcode methodology for animal species identification. The cytochrome $b$ region exhibits large interspecific and low intraspecific diversity and was proposed as a good candidate DNA barcode for vertebrates [47]. The proposed microarray-based method was able identify 71 commercial and endangered species out of 79 vertebrates.

The screening of more than 200 animals by the use of the CO1 target region suggested that DNA barcodes provide highly effective identification systems for bovid species [46]. Moreover, DNA barcoding technique based on cox 1 is considered a reliable method for traceability of mammalian meat $[46,97,98]$, as in the case of the microarray-based method successfully employed on both simple samples and mixtures (containing at least five species) as well as on fresh and degraded substrates (hair, bone, blood, muscle, and foodstuffs) [47].

The relationships between DNA barcoding sequences and species names should be critically evaluated, because the commercial name of a meat product could refer to different molecular units (the so called Molecular Operational Taxonomic Units, or MOTUs, [99]).

There are also cases of species or breeds that cannot be distinguished through the barcoding approaches, therefore making it impossible to track some meat products [100]. Obviously, the definitive way to show that closely related DNA species are different is to sequence them. As the DNA sequencing technologies are continually improving, and their costs are reducing at the same time, in a close future, genome sequencing and re-sequencing will be the tool to clarify doubtful cases.

\subsection{Fish}

The traditional fish species identification is based on morphological features, such as body shape, pattern of colors, scale size and count, number and relative position of fins, number and type of fin rays, or various relative measurements of body parts. Currently, some websites provide broad information on fish morphology [101,102]. However, once fillets are prepared from the fish, the identification is more difficult. The identification of processed fish (mincing, battering, crumbing and frying operations) is even more difficult due to the processing operations. Consequently, if the replacements of high valued fish species with low valued ones occurred, it is difficult to discover fraud.

Different types of DNA makers have been widely used in the authentication of seafood products such as RFLP [13,103,104], RAPD [83,85], SSR [105] and SNP [84].

RFLP were used to analyze a noncoding rDNA spacer segments to discriminate closely related Scombrid mackerel indicating that the rDNA spacer segments was a useful nuclear marker in the discrimination of related fish species belonging to the same genus [13].

For the detection of components in fishery products, the highly degraded DNA and the presence of additives in the canning process might interfere with the authentication of the food staff. For example, the identification of canned tuna species resulted sometime difficult, possibly as a consequence of chemical modifications that occurred to DNA of canned tuna. It should be also considered that missing 
PCR products in industrial preparation might be due to the presence of compounds with inhibitory effects on the PCR performance [106]. To eliminate these inhibitory effects, one strategy could be the amplification of DNA fragments using nested primers in two consecutive PCRs [86]. However, in salmon, it has been recently demonstrated that SNP genotyping is highly successful also in the analysis of degraded DNA samples [84].

Several researchers have also discussed the potential of DNA barcoding as a forensic tool for the traceability of edible fish $[48,49,82,107]$. For example, shark food products were analyzed using DNA barcode revealing fraudulent substitutions. Interestingly the analysis of samples of commercialized sharks, with the common name of "palombo" (belonging to the Mustelus spp., family Triakidae), collected in different Italian fish markets, revealed that out of the 45 samples analyzed, only three (6.7\%) were unequivocally assigned to "palombo" and in particular to the species M. mustelus, while six samples (13.3\%) were assigned to species of the genus Mustelus. Furthermore, 35 samples (77.8\%) were estimated species substitution [49].

The DNA barcode coxl showed a good discriminatory power in the identification of fish species: $98 \%$ of probed marine species and $93 \%$ of freshwater species were successfully identified [108]. Good results were also obtained in the analysis of small portion of fresh or processed fish foodstuff by using few universal primer combinations [109].

\subsection{Plant}

DNA markers represent a very powerful tool to authenticate and trace plant species and varieties along food chains as reported by several scientific papers [30-32,68-70,75,110]. For example, SSRs are able to identify products in different segments of the tomato food chain revealing mislabel of tomato cans indicating the premium products "San Marzano" PDO that indeed was absent [66]. Recently, a study confirmed the powerful of SSR markers for characterization and discrimination of tomato varieties using a set of 13 SSR and 47 tomato genotypes [29]. Furthermore, eight out of the 13 SSR markers were also employed to analyze three tomato mono-varietal sauces and one mixed sauce confirming, as previously demonstrated [30,31], the usefulness of the SSR markers for the authentication of processed tomato cultivars. In olive, the simultaneous detection of multiple SNPs was proposed for genotyping a set of 49 varieties. Subsequently, 12 SNP were successfully used on oil-derived DNA template, demonstrating that SNPs can be used along the olive-oil net chain [73,111]. AFLP markers were also used to evaluate varietal composition of oil samples highlighting a correspondence of 70\% between leaves and mono-varietal oil [70,71]. Several others authors reported a good match between olive oil and leaf profiles using SSR markers [32,68,74,112].

Different sets of molecular markers were used in studies on the identification of grapevine varieties [77,113-116]. It is reported that the selection of a set of few SSR markers can be used to discriminate successfully $V$. vinifera L. varieties and to trace the row material used to produce the must [33].

A reduced number of applications of DNA barcode proved effective for identification and molecular traceability of plant and plant-derived food. DNA barcoding was employed to evaluate the efficiency in separating toxic from edible species in the genus Solanum (Solanum tuberosum L., Solanum lycopersicum L. group) and Prunus (Prunus armeniaca L., Prunus avium L., Prunus cerasus L., 
Prunus domestica L.) evidencing a clear molecular distinction between the edible and the toxic congeneric [64]. De Mattia et al., in 2011 [65], analyzing a group of mint samples belonging to morphologically identified plants of congeneric species, demonstrated that DNA barcode was able to distinguish only a part of the analyzed mint samples. These authors also studied Origanum L. concluding that the DNA barcoding approach is not suitable for Origanum traceability because this genus seems to show a large genetic promiscuity. On the other hand, they successfully distinguished the Ocimum basilicum L. from the other two species under analysis (Ocimum gratissimum L. and Ocimum tenuiflorum L.). Furthermore, this paper demonstrate that the industrial processes conducted on the commercial spice samples (e.g., crumbling, drying) do not affect the success rate of DNA extraction, amplification and sequencing allowing the analysis of plant food components through a DNA barcoding approach.

The low number of successful applications of the DNA barcoding markers in plant species discrimination is generally interpreted as a consequence of the low level of inter-specific genetic variation. The identification and validation of new plant DNA barcodes form one side and the addition of other DNA markers may offer novel opportunities for genetic traceability of plant-derived food.

\section{Advantages and Limits of DNA Markers in a Traceability System}

Food authentication and protection of superior species or varieties require reliable and accurate methods of identification of genetic materials in a wide collection of fresh or processed food, without ambiguity. While the molecular authentication of fresh food may be achieved with different DNA, protein or metabolite markers, the authentication of processed food is much more challenging. In such substrates, primary or secondary metabolites are often unreliable due to severe degradation determined by farming system and processing methods while DNA, despite being altered, can be extracted and analyzed being able to provide the appropriate information for the authentication of processed foodstuff as reported by several references herein cited. However some limits must be considered. Usually it is difficult to reliably amplify fragments above 200 bp using as template DNA extracted from products, which underwent a process of thermal sterilization or physical treatments. For example, when the authentication is based on the use of SSR markers an accurate selection of SSR loci must be undertaken. Indeed, not all loci are equally useful for traceability. The ideal SSR markers must have not only a high discriminative power, but should be present on different chromosomes, with alleles included in a low molecular weight size range beside being robust, reproducible and technically simple to analyze. Furthermore, the standardization of the method of detection of SSR polymorphisms is crucial to allow the comparison of the results obtained from different labs and reduces ambiguous identifications.

Recently the major technical advances in the analysis of DNA polymorphisms have occurred in SNPs detection. These polymorphisms appear to be well distributed in the genome and are the most abundant in all living species. It is expected that millions of SNPs may be processed simultaneously using the modern sequencing technologies. In addition, SNP markers are very interesting in food traceability because the detection of their polymorphism is based on the amplification of very small fragments, even smaller than SSR alleles. Therefore, SNPs can be adapted to highly fragmented DNA, allowing rapid and efficient genotyping of large numbers of samples being also amenable to high-throughput automation. On the other hand, SNPs are in most cases biallelic and compared with 
multiallelic or multilocus markers like SSRs, they should be analyzed in a larger number in order to obtain discriminating profiles. Although much depends on the genetic structure of the species, the level of genetic variability and the selection of loci, it has been estimated that the number of SNPs from 50 to 100 provides a level of discrimination equivalent to 10-16 SSR [117]. However, the nature of the biallelic SNPs and their lower information content makes very complex the analysis of mixtures. Finally, the usefulness of SNPs, as well as all the markers that reveal polymorphisms in the sequence of the bases, should be evaluated for each matrix or food product, considering the possible chemical changes that the industrial processing or storage conditions may induce in DNA sequence.

DNA barcoding is useful in certifying both origin and quality of raw materials, and to detect adulterations in the industrial food chain. However, the main limit is in the molecular variability of the organisms and, therefore, a high level of resolution is required for organisms with low intraspecific polymorphism to make it well distinguishable from closely related taxa $[45,99]$.

\section{Conclusions}

Genetic techniques made important contributions to the food industry, with new tools for investigation and analysis. The possibility to know the identity of the genetic components of a food have assumed increasing importance even among non-specialists, thanks to the action of mass communication in the dissemination of information on the techniques of DNA analysis.

The application of these techniques to genetic traceability in the agro-food sector represents a powerful tool to protect both producers and consumers, to ensure freedom of choice and ensure the accuracy of labeling.

Molecular authentication of fresh and processed food based on DNA markers offers a valuable contribution for the identification of genetic material along the production chains since, in principle, DNA can be extracted from any food product. Finally, the application of DNA markers for the identification, characterization, and traceability of food component can improve the transparency of food production systems, helping honest producers in the protection of their food productions.

\section{Acknowledgments}

Some of the data used in this study were obtained through the activities supported by the project SALVE (Salvaguardia della Biodiversità Vegetale della Campania).

\section{Author Contributions}

R.R. conceived the organization of the data and wrote the manuscript; D.S. collected and analyzed published data and contributed to manuscript writing and preparation.

\section{Conflicts of Interest}

The authors declare no conflict of interest. 


\section{References}

1. Asensio, L.; González, I.; García, T.; Martin, R. Determination of food authenticity by enzyme-linked immunosorbent assay (ELISA). Food Control 2008, 19, 1-8.

2. Berrini, A.; Tepedino, V.; Borromeo, V.; Secchi, C. Identification of freshwater fish commercially labelled "perch" by isoelectric focusing and two-dimensional electrophoresis. Food Chem. 2006, 96, 163-168.

3. Cavaliere, B.; De Nino, A.; Hayet, F.; Lazez, A.; Macchione, B.; Moncef, C.; Perri, E.; Sindona, G.; Tagarelli, A. A metabolomic approach to the evaluation of the origin of extra virgin olive oil: A convenient statistical treatment of mass spectrometric analytical data. J. Agric. Food Chem. 2007, 55, 1454-1462.

4. Moco, S.; Forshed, J.; De Vos, R.C.; Bino, R.J.; Vervoort, J. Intra-and inter-metabolite correlation spectroscopy of tomato metabolomics data obtained by liquid chromatography-mass spectrometry and nuclear magnetic resonance. Metabolomics 2006, 4, 202-215.

5. Le Gall, G.; Puaud, M.; Colquhoun, I.J. Discrimination between orange juice and pulp wash by 1H nuclear magnetic resonance spectroscopy: Identification of marker compounds. J. Agric. Food Chem. 2001, 49, 580-588.

6. Cuny, M.; Vigneau, E.; Le Gall, G.; Colquhoun, I.; Lees, M.; Rutledge, D.N. Fruit juice authentication by $1 \mathrm{H}$ NMR spectroscopy in combination with different chemometrics tools. Anal. Bioanal. Chem. 2008, 390, 419-427.

7. Castro-Puyana, M.; Herrero, M. Metabolomics approaches based on mass spectrometry for food safety, quality and traceability. Trends Anal. Chem. 2013, 52, 74-87.

8. Ogrinc, N.K.I.J.; Košir, I.J.; Spangenberg, J.E.; Kidrič, J. The application of NMR and MS methods for detection of adulteration of wine, fruit juices, and olive oil. A review. Anal. Bioanal. Chem. 2003, 376, 424-430.

9. Martinez, I.; Aursand, M.; Erikson, U.; Singstad, T.E.; Veliyulin, E.; van der Zwaag, C. Destructive and non destructive analytical techniques for authentication and composition analyses of foodstuffs. Trends Food Sci. Technol. 2003, 14, 489-498.

10. Woolfe, M.; Primrose, S. Food forensics: Using DNA technology to combat misdescription and fraud. Trends Biotechnol. 2004, 22, 222-226.

11. Tanksley, S.D.; Bernatzky, R.; Lapitan, N.L.; Prince, J.P. Conservation of gene repertoire but not gene order in pepper and tomato. Proc. Natl. Acad. Sci. USA 1988, 85, 6419-6423.

12. Helentjaris, T. A genetic linkage map for maize based on RFLPs. Trends Genet. 1987, 3, 217-221.

13. Arahishi, F. PCR-RFLP analysis of nuclear nontranscribed spacer for mackerel species identification. J. Agric. Food Chem. 2005, 53, 508-511.

14. Bartish, I.V.; Garkava, L.P.; Rumpunen, K.; Nybom, H. Phylogenetic relationship and differentiation among and within population at Chaenomeles Lindl. (Rosaceae) estimated with RAPDs and isozymes. Theor. Appl. Genet. 2000, 101, 554-563.

15. Mokkamul, P.; Chaveerach, A.; Sudmoon, R.; Tavee, T. Species identification and sex determination of the genus Nepenthes (Nepenthaceae). Pak. J. Biol. Sci. 2007, 10, 561-567. 
16. Verma, S.; Karihaloo, J.L.; Tiwari, S.K.; Magotra, R.; Koul, A.K. Genetic diversity in Eremostachys superba Royle ex Benth (Lamiaceae), an endangered Himalayan species, as assessed by RAPD. Genet. Resour. Crop Evol. 2007, 54, 221-229.

17. Zhang, J.Y.; Yuan, Q.H.; Meng, Y.Q.; Li, X.L.; Nan, Z.B.; Wang, Y.R.; Zhang, W.S. A genetic diversity analysis of wild Lespedeza papulalois based on morphological characters, allozymes and RAPD methods. Plant Breed. 2007, 126, 89-94.

18. Chaveerach, A.; Tanomtang, A.; Sudmood, R.; Tanee, T. Genetic diversity among geographically distributed population of Nepenthes mirabilis. Biologia (Bratislava) 2006, 61, 295-298.

19. Wu, S.H.; Hwang, C.Y.; Lin, T.P.; Chung, J.D.; Cheng, Y.P.; Hwang, S.Y. Contrasting phylogeographical patterns of two closely related species, Machilus thunbergii and Machilus kusanoi (Lauraceae), in Taiwan. J. Biogeogr. 2006, 33, 936-947.

20. Jones, C.J.; Edwards, K.J.; Castaglione, S.; Winfield, M.O.; Sala, F.; Van de Wiel, C.; Bredemeijer, G.; Vosman, B.; Matthes, M.; Daly, A.; et al. Reproducibility testing of RAPD, AFLP and SSR markers in plants by a network of European laboratories. Mol. Breed. 1997, 3, 381-390.

21. Rao, R.; La Mura, M.; Corrado, G.; Ambrosino, O.; Foroni, I.; Perri, E.; Pugliano, G. Molecular diversity and genetic relationships of southern Italian olive cultivars as depicted by AFLP and morphological traits. J. Hortic. Sci. Biotechnol. 2009, 84, 261-266.

22. Angiolillo, A.; Mencuccini, M.; Baldoni, L. Olive genetic diversity assessed using amplified fragment length polymorphisms. Theor. Appl. Genet. 1999, 98, 411-421.

23. Rotondi, A.; Magli, M.; Ricciolini, C.; Baldoni, L. Morphological and molecular analyses for the characterization of a group of Italian olive cultivars. Euphytica 2003, 132, 129-137.

24. Ajmone-Marsan, P.; Vecchiotti-Antaldi, G.; Bertoni, G.; Valentini, A.; Cassandro, M.; Kuiper, M. AFLPTM markers for DNA fingerprinting in cattle. Anim. Genet. 1997, 28, 418-426.

25. Zane, L.; Bargelloni, L.; Patarnello, T. Strategies for microsatellite isolation: A review. Mol. Ecol. 2002, 11, 1-16.

26. Powell, W.; Machray, G.C.; Provan, J. Polymorphism revealed by simple sequence repeats. Trends Plant Sci. 1996, 1, 215-222.

27. Orrù, L.; Napolitano, F.; Catillo, G.; Moioli, B. Meat molecular traceability: How to choose the best set of microsatellites? Meat Sci. 2006, 72, 312-317.

28. Arana, A.; Soret, B.; Lasa, I.; Alfonso, L. Meat traceability using DNA markers: Application to the beef industry. Meat Sci. 2002, 61, 367-373.

29. Sardaro, S.M.L.; Marmiroli, M.; Maestri, E.; Marmiroli, N. Genetic characterization of Italian tomato varieties and their traceability in tomato food products. J. Nutr. Food Sci. 2013, 1, 54-62.

30. Caramante, M.; Corrado, G.; Monti, L.M.; Rao, R. Simple Sequence Repeats are able to trace tomato cultivars in tomato food chains. Food Control 2010, 22, 549-554.

31. Turci, M.; Sardaro, M.L.S.; Visioli, G.; Maestri, G. Evaluation of DNA extraction procedures for traceability of various tomato products. Food Control 2010, 21, 143-149.

32. Corrado, G.; Imperato, A.; la Mura, M.; Perri, E.; Rao, R. Genetic diversity among olive varieties of southern Italy and the traceability of olive oil using SSR markers. J. Hortic. Sci. Biotechnol. 2011, 86, 461-466. 
33. Pereira, L.; Martins-Lopes, P.; Batista, C.; Zanol, G.C.; Clímaco, P.; Brazão, J.; Eiras-Dias, J.E.; Guedes-Pinto, H. Molecular Markers for Assessing Must Varietal Origin. Food Anal. Methods 2012, 5, 1252-1259.

34. Parida, S.K.; Kalia, S.K.; Sunita, K.; Dalal, V.; Hemaprabha, G.; Selvi, A.; Pandit, A.; Singh, A.; Gaikwad, K.; Sharma, T.R.; et al. Informative genomic microsatellite markers for efficient genotyping applications in sugarcane. Theor. Appl. Genet. 2009, 118, 327-338.

35. Varshney, K.R.; Terauchi, R.; McCouch, S.R. Harvesting the Promising Fruits of Genomics: Applying Genome Sequencing Technologies to Crop Breeding. PLoS Biol. 2014, 12, e1001883.

36. Sim, S.C.; van Deynze, A.; Stoffel, K.; Douches, D.S.; Zarka, D.; Ganal, M.W.; Chetelat, R.T.; Hutton, S.F.; Scott, J.W.; Gardner, R.G.; et al. High-density SNP genotyping of tomato (Solanum lycopersicum L.) reveals patterns of genetic variation due to breeding. PLoS One 2012, 7, e45520.

37. Corrado, G.; Piffanelli, P.; Caramante, M.; Coppola, M.; Rao, R. SNP genotyping reveals genetic diversity between cultivated landraces and contemporary varieties of tomato. BMC Genomics 2013, 14, 835-849.

38. Corrado, G.; Caramante, M.; Piffanelli, P.; Rao, R. Genetic diversity in Italian tomato landraces: Implications for the development of a core collection. Sci. Hortic. 2014, 168, 138-144.

39. Fang, W.; Meinhardt, L.W.; Mischke, S.; Bellato, C.M.; Motilal, L.; Zhang, D. Accurate determination of genetic identity for a single cacao bean, using molecular markers with a nanofluidic system, ensures cocoa authentication. J. Agric. Food Chem. 2013, 62, 481-487.

40. Chase, M.W.; Cowan, R.S.; Hollingsworth, P.M.; van den Berg, C.; Madrinan, S.; Petersen, G.; Seberg, O.; Jørgsensen, T.; Cameron, K.M.; Carine, M.; et al. A proposal for a standardised protocol to barcode all land plants. Taxon 2007, 56, 295-299.

41. Fazekas, A.J.; Kesanakurti, P.R.; Burgess, K.S.; Percy, D.M.; Graham, S.W.; Barrett, S.C.H.; Newmaster, S.G.; Hajibabaei, M.; Husband, B.C. Are plant species inherently harder to discriminate than animal species using DNA barcoding markers? Mol. Ecol. Resour. 2009, 9, $130-139$.

42. Kress, W.J.; Erickson, D.L.; Jones, F.A.; Swenson, N.G.; Perez, R.; Sanjur, O.; Bermingham, E. Plant DNA barcodes and a community phylogeny of a tropical forest dynamics plot in Panama. Proc. Natl. Acad. Sci. USA 2009, 106, 18621-18626.

43. Burgess, K.S.; Fazekas, A.J.; Kesanakurti, P.R.; Graham, S.W.; Husband, B.C.; Newmaster, S.G.; Percy, D.M.; Hajibabaei, M.; Barrett, S.C.H. Discriminating plant species in a local temperate flora using the rbcL+matK DNA barcode. Methods Ecol. Evol. 2011, 2, 333-340.

44. Small, R.L.; Cronn, R.C.; Wendel, J.F. Use of nuclear genes for phylogeny reconstruction in plants. Aust. Syst. Bot. 2004, 17, 145-170.

45. Hebert, P.D.N.; Cywinska, A.; Ball, S.L.; de Waard, J.R. Biological identifications through DNA barcodes. Proc. R. Soc. Lond. Ser. B Biol. Sci. 2003, 270, 313-322.

46. Cai, Y.S.; Zhang, L.A.; Shen, F.J.; Zhang, W.P.; Hou, R.; Yue, B.S.; Li, J.; Zhang, Z.H. DNA barcoding of 18 species of Bovidae. Chin. Sci. Bull. 2011, 56, 164-168.

47. Teletchea, F.; Bernillon, J.; Duffraisse, M.; Laudet, V.; Hänni, C. Molecular identfication of vertebrate species by oligonucleotide microarray in food and forensic samples. J. Appl. Ecol. 2008, 45, 967-975. 
48. Filonzi, L.; Chiesa, S.; Vaghi, M.; Nonnis Marzano, F. Molecular barcoding reveals mislabelling of commercial fish products in Italy. Food Res. Int. 2010, 43, 1383-1388.

49. Barbuto, M.; Galimberti, A.; Ferri, E.; Labra, M.; Malandra, R.; Galli, P.; Casiraghi, M. DNA barcoding reveals fraudulent substitutions in shark seafood products: The Italian case of "palombo" (Mustelus spp.). Food Res. Int. 2010, 43, 376-381.

50. Galtier, N. The intriguing evolutionary dynamics of plant mitochondrial DNA. BMC Biol. 2011, 9,61 .

51. Kress, W.J.; Erickson, D.L. A two-locus global DNA barcode for land plants: The coding rbcL gene complements the non-coding trnH-psbA apacer region. PLoS One 2007, 2, e508.

52. Lahaye, R.; van der Bank, M.; Bogarin, D.; Warner, J.; Pupulin, F.; Gigot, G.; Maurin, O.; Duthoit, S.; Barraclough, T.G.; Savolainen, V. DNA barcoding the floras of biodiversity hotspots. Proc. Natl. Acad. Sci. USA 2008, 106, 12794-12797.

53. CBOL Plant Working Group. A DNA barcode for land plants. Proc. Natl. Acad. Sci. USA 2009, 106, 12794-12797.

54. BOLD Systems. Available online: www.barcodinglife.org (accessed on 2 September 2014).

55. Ratnasingham, S.; Hebert, P.D. BOLD: The Barcode of Life Data System (http://www. barcodinglife. org). Mol. Ecol. Notes 2007, 7, 355-364.

56. Hebert, P.D.; Stoeckle, M.Y.; Zemlak, T.S.; Francis, C.M. Identification of birds through DNA barcodes. PLoS Biol. 2004, 2, e312.

57. Meier, R.; Shiyang, K.; Vaidya, G.; Ng, P.K. DNA barcoding and taxonomy in Diptera: A tale of high intraspecific variability and low identification success. Syst. Biol. 2006, 55, 715-728.

58. Victor, B.C. Redescription of Coryphopterus tortugae (Jordan) and a new allied species Coryphopterus bol (Perciformes: Gobiidae: Gobiinae) from the tropical western Atlantic Ocean. J. Ocean Sci. Found. 2008, 1, 1-19.

59. Smith, P.J.; Steinke, D.; McVeagh, M.S.; Stewart, A.L.; Struthers, C.D.; Roberts, C. Molecular analysis of Southern Ocean skates (Bathyraja) reveals a new species of Antarctic skate. J. Fish Biol. 2008, 73, 1170-1182.

60. Last, P.R.; Gledhill, D.C.; Holmes, B.H. A new handfish, Brachionichthys australis sp. nov. (Lophiiformes: Brachionichthyidae), with a redescription of the critically endangered spotted handfish, B. hirsutus (Lacepede). Zootaxa 2007, 1666, 53-68.

61. Pyle, R.L.; Earle, J.L.; Greene, B.D. Five new species of the damselfish genus Chromis (Perciformes: Labroidei: Pomacentridae) from deep coral reefs in the tropical western Pacific. Zootaxa 2008, 1671, 3-31.

62. Regattieri, A.; Gamberi, M.; Manzini, R. Traceability of food products: General framework and experimental evidence. J. Food Eng. 2007, 81, 347-356.

63. Mafra, I.; Ferreira, I.M.; Oliveira, M.B.P.P. Food authentication by PCR-based methods. Eur. Food Res. Technol. 2008, 227, 649-665.

64. Bruni, I.; de Mattia, F.; Galimberti, A.; Galasso, G.; Banfi, E.; Casiraghi, M.; Labra, M. Identification of poisonous plants by DNA barcoding approach. Int. J. Leg. Med. 2010, 124, 595-603. 
65. De Mattia, F.; Bruni, I.; Galimberti, A.; Cattaneo, F.; Casiraghi, M.; Labra, M. A comparative study of different DNA barcoding markers for the identifcation of some members of Lamiacaea. Food Res. Int. 2011, 44, 693-702.

66. Scarano, D.; Corrado, G.; Caramante, M.; Rao, R. SSR fingerprinting reveals mislabelling of commercial "San Marzano" tomato products. Minerva Biotecnol. 2011, 23, 42-44.

67. Sonnante, G.; Montemurro, C.; Morgese, A.; Sabetta, W.; Blanco, A.; Pasqualone, A. DNA microsatellite region for a reliable quantification of soft wheat adulteration in durum wheat-based food- stuffs by Real-Time PCR. J. Agric. Food Chem. 2009, 57, 10199-10204.

68. Pasqualone, A.; Montemurro, C.; Summo, C.; Sabetta, W.; Caponio, F.; Blanco, A. Effectiveness of microsatellite DNA markers in checking the identity of protected designation of origin extra virgin olive oil. J. Agric. Food Chem. 2007, 55, 3857-3862.

69. Melchiade, D.; Foroni, I.; Corrado, G.; Santangelo, I.; Rao, R. Authentication of the "Annurca" apple in agro-food chain by ampli- fication of microsatellites loci. Food Biotechnol. 2007, 21, 33-43.

70. Montemurro, C.; Pasqualone, A.; Simeone, R.; Sabetta, W.; Blanco, A. AFLP molecular markers to identify virgin olive oils from single Italian cultivars. Eur. Food Res. Technol. 2008, 226, 1439-1444.

71. Pafundo, S.; Agrimonti, C.; Marmiroli, N. Traceability of plant contribution in olive oil by amplified fragment length polymorphisms. J. Agric. Food Chem. 2005, 53, 6995-7002.

72. Martins-Lopes, P.; Gomes, S.; Santos, E.; Guedes-Pinto, H. DNA Markers for Portuguese olive oil fingerprinting. J. Agric. Food Chem. 2008, 56, 11786-11791.

73. Consolandi, C.; Palmieri, L.; Severgnini, M.; Maestri, E.; Marmiroli, N.; Agrimonti, C.; Baldoni, L.; Donini, P.; de Bellis, G.; Castiglioni, B. A procedure for olive oil traceability and authenticity: DNA extraction, multiplex PCR and LDR-universal array analysis. Eur. Food Res. Technol. 2008, 227, 1429-1438.

74. Alba, V.; Sabetta, W.; Blanco, A.; Pasqualone, A.; Montemurro, C. Microsatellite marker to identify specific alleles in DNA extracted from monovarietal virgin olive oils. Eur. Food Res. Technol. 2009, 229, 375-382.

75. Terzi, V.; Morcia, C.; Giovanardi, D.; D’Egidio, M.G.; Stanca, A.M.; Faccioli, P. DNA-based analysis for authenticity assessment of monova-rietal pasta. Eur. Food Res. Technol. 2004, 219 , 428-431.

76. Chuang, H.; Lur, H.; Hwu, K.; Chang, M. Authentication of domestic Taiwan rice varieties based on fingerprinting analysis of microsatellite DNA markers. Bot. Stud. 2011, 52, 393-405.

77. Cunha, J.; Santos, M.T.; Carneiro, L.C.; Fevereiro, P.; Eiras-Dias, J.E. Portuguese traditional grapevine cultivars and wild vines (Vitis vinifera L.) share morphological and genetic traits. Genet. Resour. Crop Evol. 2009, 56, 975-989.

78. Shackell, G.H.; Tate, M.L.; Anderson, R.M. Installing a DNA-based traceability system in the meat industry. Proc. Assoc. Adv. Anim. Breed. Genet. 2001, 14, 533-536.

79. Mane, B.G.; Tanwar, V.K.; Girish, P.S.; Dixit, V.P. Identification of species origin of meat by RAPD-PCR technique. J. Vet. Public Health 2006, 4, 87-90. 
80. Goffaux, F.; China, B.; Dams, L.; Clinquart, A.; Daube, G. Development of a genetic traceability test in pig based on single nucleotide polymorphism detection. Forensic Sci. Int. 2005, 151, 239-247.

81. Jérôme, M.; Martinsohn, J.T.; Ortega, D.; Carreau, P.; Verrez-Bagnis, V.; Mouchel, O. Toward fish and seafood traceability: Anchovy species determination in fish products by molecular markers and support through a public domain database. J. Agric. Food Chem. 2008, 56, 3460-3469.

82. Di Pinto, A.; Di Pinto, P.; Terio, V.; Bozzo, G.; Bonerba, E.; Ceci, E.; Tantillo, G. DNA barcoding for detecting market substitution in salted cod fillets and battered cod chunks. Food Chem. 2013, 141, 1757-1762.

83. Yamazaki, Y.; Fukutomi, N.; Oda, N.; Shibukawa, K.; Niimura, Y.; Iwata, A. Occurrence of larval Pacific lamprey Entosphenus tridentatus from Japan, detected by random amplified polymorphic DNA (RAPD) analysis. Ichthyol. Res. 2005, 52, 297-301.

84. Johnston, S.E.; Lindqvist, M.; Niemelä, E.; Orell, P.; Erkinaro, J.; Kent, M.P.; Sigbjørn, L.; Vähä, J.; Vasemägi, A.; Primmer, C.R. Fish scales and SNP chips: SNP genotyping and allele frequency estimation in individual and pooled DNA from historical samples of Atlantic salmon (Salmo salar). BMC Genomics 2013, 14, 439-452.

85. Jin, L.G.; Cho, J.G.; Seong, K.B.; Park, J.Y.; Kong, I.S.; Hong, Y.K. 18 rRNA gene sequences and random amplified polymorphic DNA used in discriminating Manchurian trout from other freshwater salmonids. Fish. Sci. 2006, 72, 903-905.

86. Pardo, M.A.; Perez-Villareal, B. Identification of commercial canned tuna species by restriction site analysis of mitochondrial DNA products obtained by nested primer PCR. Food Chem. 2004, $86,143-150$.

87. Sakaridis, I.; Ganopoulos, I.; Argiriou, A.; Tsaftaris, A. A fast and accurate method for controlling the correct labeling of products containing buffalo meat using High Resolution Melting (HRM) analysis. Meat Sci. 2013, 94, 84-88.

88. Casellas, J.; Jimenez, N.; Fina, M.; Tarres, J.; Sanchez, A.; Piedrafita, J. Genetic diversity measures of the bovine Alberes breed using microsatellites, variability among herds and types of coat colour. J. Anim. Breed. Genet. 2004, 121, 101-110.

89. Dalvit, C.; De Marchi, M.; Targhetta, C.; Gervaso, M.; Cassandro, M. Genetic traceability of meat using microsatellite markers. Food Res. Int. 2008, 41, 301-307.

90. Felmer, R.; Sagredo, B.; Chávez, R.; Iraira, S.; Folch, C.; Parra, L.; Catrileo, A.; Ortiz, M. Implementation of a molecular system for traceability of beef based on microsatellite markers. Chil. J. Agric. Res. 2008, 68, 342-351.

91. Conyers, C.M.; Allnutt, T.R.; Hird, H.J.; Kaye, J.; Chisholm, J. Development of a microsatellite-based method for the differentiation of European wild boar (Sus scrofa scrofa) from domestic pig breeds (Sus scrofa domestica) in food. J. Agric. Food Chem. 2012, 60, 3341-3347.

92. Fernández, M.E.; Goszczynski, D.E.; Lirón, J.P.; Villegas-Castagnasso, E.E.; Carino, M.H.; Ripoli, M.V.; Rogberg-Muñoz, A.; Posik, D.M.; Peral-García, P.; Giovambattista, G. Comparison of the effectiveness of microsatellites and SNP panels for genetic identification, traceability and assessment of parentage in an inbred Angus herd. Genet. Mol. Biol. 2013, 36, 185-191. 
93. Capoferri, R.; Galli, A.; Bongioni, G. Molecular traceability in meat producing animals by SnPs. In Proceedings of the 4th World Italian Beef Cattle Congress, Gubbio, Italy, 29 April-1 May 2005.

94. Rohrer, G.A.; Freking, B.A.; Nonneman, D. Single nucleotide polymorphisms for pig identification and parentage exclusion. Anim. Genet. 2007, 38, 253-258.

95. Ramos, A.M.; Crooijmans, R.P.; Affara, N.A.; Amaral, A.J.; Archibald, A.L.; Beever, J.E.; Bendixen, C.; Churcher, C.; Clark, R.; Dehais, P.; et al. Design of a high density SNP genotyping assay in the pig using SNPs identified and characterized by next generation sequencing technology. PLoS One 2009, 4, e6524.

96. Wilkinson, S.; Archibald, A.L.; Haley, C.S.; Megens, H.J.; Crooijmans, R.P.; Groenen, M.A.; Wiener, P.; Ogden, R. Development of a genetic tool for product regulation in the diverse British pig breed market. BMC Genomics 2012, 13, 580.

97. Francis, C.M.; Borisenko, A.V.; Ivanova, N.V.; Eger, J.L.; Lim, B.K.; Guillén-Servent, A.; Kruskop, S.V.; Mackie, I.; Hebert, P.D.N. The role of DNA barcodes in understanding and conservation of mammal diversity in Southeast Asia. PLoS One 2010, 5, e12575.

98. Luo, A.R.; Zhang, A.B.; Ho, S.Y.W.; Xu, W.J.; Zhang, Y.Z.; Shi, W.F.; Cameron, S.L.; Zhu, C. Potential efficacy of mitochondrial genes for animal DNA barcoding: A case study using eutherian mammals. BMC Genomics 2011, 12, 84-97.

99. Casiraghi, M.; Labra, M.; Ferri, E.; Galimberti, A.; de Mattia, F. DNA barcoding: A six-question tour to improve users' awareness about the method. Brief. Bioinform. 2010, 11, 440-453.

100. Galimberti, A.; de Mattia, F.; Losa, A.; Bruni, I.; Federici, S.; Casiraghi, M.; Martellos, S.; Labra, M. DNA barcoding as a new tool for food traceability. Food Res. Int. 2013, 50, 55-63.

101. FishBase. Available online: www.fishbase.org (accessed on 2 September 2014).

102. Pescabase. Available online: www.pescabase.org (accessed on 2 September 2014). (In Spanish)

103. Colombo, F.; Cerioli, M.; Colombo, M.M.; Marchisio, E.; Malandra, R.; Renon, P. A simple polymerase chain reactionerestriction fragment length polymorphism (PCR-RFLP) method for the differentiation of cephalopod mollusc families Loliginidae from Ommastrephidae, to avoid substitutions in fishery field. Food Control 2002, 13, 185-190.

104. Lin, W.F.; Hwang, D.F. Application of PCR-RFLP analysis on species identification of canned tuna. Food Control 2007, 18, 1050-1057.

105. Renshaw, M.A.; Saillant, E.; Broughton, R.E.; Gold, J.R. Application of hypervariable genetic markers to forensic identification of "wild" from hatchery-raised red drum, Sciaenops ocellatus. Forensic Sci. Int. 2006, 156, 9-15.

106. Wilson, I.G. Inhibition and facilitation of nucleic acid amplification. Appl. Environ. Microbiol. 1997, 63, 3741-3751.

107. Smith, P.J.; McVeagh, S.M.; Steinke, D. DNA barcoding for the identification of smoked fish products. J. Fish Biol. 2008, 72, 464-471.

108. Ward, R.D.; Hanner, R.; Hebert, P.D.N. The campaign to DNA barcode all fishes, FISH-BOL. J. Fish Biol. 2009, 74, 329-356.

109. Steinke, D.; Hanner, R. The FISH-BOL collaborators' protocol. Mitochondrial DNA 2011, 22, $10-14$.

110. Scarano, D.; Montemurro, C.; Corrado, G.; Blanco, A.; Rao, R. DNA markers as a tool for genetic traceability of primary product in agri-food chains. Ital. J. Agron. 2012, 7, 346-350. 
111. Consolandi, C.; Palmieri, L.; Doveri, S.; Maestri, E.; Marmiroli, N.; Reale, S.; Lee, D.; Baldoni, L.; Tosti, N.; Severgnini, M.; et al. Olive variety identification by ligation detection in a universal array format. J. Biotecnol. 2007, 129, 565-574.

112. Testolin, R.; Lain, O. DNA extraction from olive oil and PCR amplification of microsatellite markers. Food Chem. Toxicol. 2005, 70, 108-112.

113. Moreno, S.; Martin, J.P.; Ortiz, J.M. Inter-simple sequence repeats PCR for characterization of closely related grapevine germplasm. Euphytica 1998, 110, 117-125.

114. Herrera, R.; Cares, V.; Wilkinson, M.; Caligari, P.D.S. Characterization of the genetic variation and cultivar identification of Vitis vinifera cultivars using RAPD and anchored microsatellites markers. Euphytica 2002, 124, 139-145.

115. Fanizza, G.; Chaabane, R.; Lamaj, F.; Ricciardi, L.; Resta, P. AFLP analysis of genetic relationships among aromatic grapevines (Vitis vinifera). Theor. Appl. Genet. 2003, 107, $1043-1047$.

116. Benjak, A.; Ercisli, S.; Vokurka, A.; Maletic, E.; Pejic, I. Genetic relationships among grapevine cultivars native to Croatia, Greece and Turkey. Vitis 2005, 44, 73-77.

117. Singh, N.; Choudhury, D.R.; Singh, A.K.; Kumar, S.; Srinivasan, K.; Tyagi, R.K.; Singh, N.K. Comparison of SSR and SNP Markers in Estimation of Genetic Diversity and Population Structure of Indian Rice Varieties. PLoS One 2013, 8, e84136.

(C) 2014 by the authors; licensee MDPI, Basel, Switzerland. This article is an open access article distributed under the terms and conditions of the Creative Commons Attribution license (http://creativecommons.org/licenses/by/3.0/). 